\title{
Effects of prescribed fires on the survival and release of seeds of Kielmeyera coriacea (Spr.) Mart. (Clusiaceae) in savannas of Central Brazil
}

\author{
Paulo Cirne $^{1}$ and Heloisa Sinátora Miranda ${ }^{2 *}$
}

${ }^{1}$ Departamento de Ecologia, Instituto de Ciências Biológicas, Universidade de Brasília, Brasília, Brazil. ${ }^{2}$ Universidade de Brasília, Departamento de Ecologia,70910-900 - Brasília - DF. Phone 61 3307-2326 R/12. *Corresponding author:hmiranda@unb.br

Received: 7 August 2008; Accepted: 6 November 2008

Effects of prescribed fires on survival and release of seeds of the woody species Kielmeyera coriacea (Clusiaceae) were investigated in two plots of cerrado sensu stricto, a savanna vegetation of Central Brazil. The first plot was burnt in June, at the beginning of the dry season, and the second in August, in the middle of the dry season. Seed survival was measured after fire in both areas and related to internal and external fruit temperatures measured during the June fire. The proportion of open fruits per individual of $K$. coriacea was also assessed at two-week intervals. Maximum external temperatures during fire $\left(393\right.$ to $\left.734^{\circ} \mathrm{C}\right)$ were strongly reduced inside the fruits $\left(61\right.$ to $\left.63^{\circ} \mathrm{C}\right)$. Before the June fire, the majority of the fruits were closed in both plots. Most fruits in the June plot opened within two weeks following the burning while, in the same period, most fruits remained closed in the August plot. Fifteen days after the prescribed fire in the August plot most fruits opened, as observed in the June plot. No germination was observed in seeds from closed fruits collected before the fire, while those from fruits that were closed during the burning showed a high mean germination rate (June $=79 \pm 12 \%$; August $=69 \pm 14 \%$ ). The results indicate that fruits of $K$. coriacea are good insulators for seeds during fires and that seed release is anticipated independently of the burning season. Key words: Cerrado, fire season, fruit temperature, germination, seed release

Efeito de queimadas prescritas na sobrevivência e dispersão de sementes de Kielmeyera coriacea (Spr.) Mart. (Clusiaceae) em áreas de cerrado sensu stricto: Os efeitos de queimadas prescritas na sobrevivência e na dispersão de sementes de Kielmeyera coriacea (Clusiaceae) foram investigados em duas parcelas de cerrado sensu stricto, uma queimada no início da estação seca (junho) e outra, em agosto, meio da estação seca. A sobrevivência das sementes após as queimadas foi relacionada às temperaturas externa e interna dos frutos medidas durante a queimada de junho. A proporção de frutos abertos por indivíduos de $K$. coriacea foi observada quinzenalmente. As temperaturas externas máximas durante a passagem do fogo $\left(393\right.$ a $\left.734^{\circ} \mathrm{C}\right)$ foram fortemente reduzidas dentro dos frutos $\left(61\right.$ a $\left.63^{\circ} \mathrm{C}\right)$. Nas duas parcelas, a maior parte dos frutos estava fechada antes da queimada realizada em junho. Cerca de $60 \%$ dos frutos observados na parcela queimada em junho abriram nas duas semanas após a queimada sendo que, no mesmo período, a maior parte dos frutos na parcela a ser queimada em agosto permaneceu fechada. Da mesma forma, nas duas semanas seguintes à queimada realizada em agosto, foi observada a abertura da maioria dos frutos. Nenhuma semente dos frutos coletados antes das queimadas germinou. Entretanto, foi alta a germinação das sementes coletadas dos frutos que estavam fechados durante as queimadas (junho $=79 \pm 12 \%$; agosto $=69 \pm 14 \%$ ). Os resultados indicam que os frutos de K. coriacea oferecem boa proteção para as sementes durante as queimadas e que, independentemente da época da queima, a dispersão das sementes é antecipada pela passagem do fogo.

Palavras-chave: Cerrado, fogo, temperatura do fruto, germinação, dispersão de sementes 


\section{INTRODUCTION}

Fire is considered to be an important ecological feature in several plant communities creating opportunities for establishment, growth and reproduction of many species, and restraining the less resistant ones (Whelan, 1995; Cirne and Scarano, 2001; Cirne et al., 2003). In areas with high susceptibility and recurrence of burning, some fire-related characteristics tend to be selected, and the success of each is determined by intrinsic (anatomical, morphological, physiological and growth patterns) and extrinsic factors such as climate and fire regime (Lamont et al., 1991; Tyler, 1995; Hanley and Fenner, 1997). Studies concerning the components of the fire regime, such as season of burning, are particularly important for understanding patterns of plant distribution and different regeneration strategies, especially in areas with climatic seasonality (Bond, 1984; Cowling and Lamont, 1987; Williams et al., 2004).

At the individual level, the survival of a plant will depend on the amplitude and duration of the temperatures during fire, since an increase in temperature will correspond to a decrease in the period of exposure required to promote injury in living tissues (Wright and Bailey, 1982). In the case of seeds, thermal insulation can be improved if they are buried in the soil and/or have a hard coat (Lamont and Baker, 1988; Auld and O`Connell, 1991; Eriksson et al., 2003), by fruit location in the plant (Judd and Ashton, 1991; Judd, 1993), or by a thick fruit wall or high moisture content of fruits (Judd, 1994; Bradstock et al., 1994; Mercer et al., 1994; Bell and Williams, 1998). Few studies report direct field measurements quantifying the reduction of temperatures by fruits during fires (Judd, 1993; Bradstock et al., 1994).

For many species, fruit opening may be anticipated by fire, as has been reported for some wind-dispersed plants of the Cerrado (Coutinho, 1977), a savanna vegetation in Central Brazil. Natural or human initiated fires have been a feature of this Biome for more than 32,000 years (SalgadoLabouriau and Ferraz-Vicentini, 1994). The alteration in species composition and vegetation structure as a consequence of a high fire frequency on the Cerrado vegetation (Medeiros and Miranda, 2005, 2008), together with the replacement of the native vegetation by crops and pastures, has included the Cerrado in the list of 25 world biodiversity "hotspots" (Myers et al., 2000;
Cardoso and Bates, 2002). Research on the effects of different fire regimes, especially the burning season, on the reproduction of Cerrado vegetation is important for its conservation.

This study examined the importance of the fruits of Kielmeyera coriacea (Clusiaceae) as thermal insulators for seeds during the fire in a cerrado sensu stricto with a dense cover of shrubs and trees and a rich grass understory, the most common Cerrado phytophysiognomy (Eiten, 1972). The effects of time of fire (beginning and middle of the dry season) on seed release were analyzed. The following questions were addressed: 1) Are $K$. coriacea fruits good insulators for seeds during fires? 2) Are seeds in open fruits and those protected in closed fruits capable of surviving a fire? 3) Does the fire season alter the natural phenological patterns of $K$. coriacea fruit opening and seed release?

\section{MATERIAL AND METHODS}

The study was carried out in the Reserva Ecológica do Instituto Brasileiro de Geografia e Estatística, $35 \mathrm{~km}$ south of Brasília (1556’41"S, 4753’7"W), Brazil. The Reserve has an area of 1360 ha at an altitude of $1100 \mathrm{~m}$, and the mean annual precipitation is $1353 \mathrm{~mm}$.

Two contiguous plots (10 ha each, $200 \mathrm{~m}$ x $500 \mathrm{~m}$ ) of cerrado sensu stricto were used in the study. Both plots had been protected from fire for 18 years until 1992. Since 1992, one of the plot has been burned biennially in June (beginning of the dry season) and the other, in August (middle of the dry season). The biennial fire frequency has been applied to simulate the most common fire frequency in the region (Coutinho, 1982).

The native species, Kielmeyera coriacea can be found in most Cerrado physiognomic forms, and is one of the few woody species which dominates the more open physiognomies of this biome (Aoki and Santos, 1982; Ribeiro et al., 1985). Some individuals may reach up to $8 \mathrm{~m}$ in height (Almeida et al., 1998), and its phenological patterns are markedly seasonal: complete fall of leaves during one or two months of the dry season and flower production from September to January, beginning to middle of the rainy season. The fruits are dehiscent and large, $16 \mathrm{~cm}$ length by $5 \mathrm{~cm}$ width, with an average of 63 seeds per fruit. After a long period of maturation, lasting most of the subsequent dry season, the fruits are totally 
open and the seeds can be easily detached and dispersed by wind in synchrony with the beginning of the rains (Ribeiro et al., 1985; Oliveira and Silva, 1993; Landim and Hay, 1996).

The role of $K$. coriacea fruits in protecting the seeds during fires was investigated, during the prescribed fire of June 2000, by measuring external temperature at the fruit surface and the internal temperature near the seeds. Seed position inside the fruits was estimated from laboratory observations of seed position in relation to fruit size. Temperatures in three fruits were measured with thermocouples type k (30 swg), recorded at one second interval and stored automatically in a data logger (21X, Campbell Scientific, Inc., E.U.A.). In both plots, the mean fruit height was $2.1 \pm 0.8 \mathrm{~m}$, and the sampled fruits were located between $2.0 \mathrm{~m}$ and $2.3 \mathrm{~m}$ in height.

Seed survival in both areas was analyzed through germinability of seeds collected in fruits opening after the prescribed fires. Immediately after the June and August burns, 20 to 25 closed fruits, from different individual plants, were covered with cotton net bags to ensure no loss of seeds after fruit opening. Seeds from 10 fruits that opened in the week following the fires were collected for germination test. Ten samples, with 10 seeds each, were used for each plot. The seeds were placed in Petri dishes with wet filter paper to germinate at room temperature and light conditions. Newly germinated seeds were counted daily. The geotropic curvature of the radicle was used as the germination criterion. The significance of differences between the germination rates of seeds collected in fruits opened after the June and August fires was tested (t test; Zar, 1996), after arcsine transformation. The same methods and sample size were used to obtain the germination rate of seeds from closed fruits collected immediately before the June and August fires, and for seeds collected, immediately after the fires, from fruits that were open in the plots. Closed fruits were opened manually to collect the seeds and, to avoid any effect of storage, all germination tests were carried out immediately after seed collection.

To analyze the effect of burning and fire season on the time of fruit opening and seed release, 15 individuals, with a minimum of three fruits each, were tagged in each plot. Total number of fruits in the tagged trees was 114 in the June plot and 125 in the August plot. The proportion of open fruits was observed at two-week intervals, before and after the fires. The significance of the differences between the values observed in consecutive weeks was tested by the Mann-Whitney test $(\alpha=0.05)$. The proportion of open fruits in the August plot was used as control (i.e. without fire) for the plot burnt in June.

The relative water content (water mass/dry mass) was determined for 10 closed fruits collected one hour before the prescribed fire in June and for another 10 closed fruits collected 15 days after the fire. Fruit fresh mass was measured in the field and the dry mass was obtained after drying the fruits at $80^{\circ} \mathrm{C}$ until constant mass. Ten closed fruits collected in the June plot, 15 days after the fire, were used to estimate the relative water content for the fruits to open. Relative water content was also measured for 10 fruits collected one hour before the fire in the August plot. The significance of differences between the relative water content was tested (t test; Zar, 1996).

\section{RESULTS}

The increase in temperature was 19 times greater at fruit surface than inside the fruit. Maximal external fruit temperatures during the fire ranged from $393^{\circ} \mathrm{C}$ to $734^{\circ} \mathrm{C}$ (Figure 1a) with a mean value $\pm \mathrm{SD}$ of $597 \pm 180^{\circ} \mathrm{C}$. Internal fruit temperatures (Figure $1 \mathrm{~b}$ ) were in the range of $61^{\circ} \mathrm{C}$ to $63^{\circ} \mathrm{C}$ with a mean value of $62 \pm 1^{\circ} \mathrm{C}$. At the fruit surface, temperatures greater than $60^{\circ} \mathrm{C}$ were observed for $106 \pm 19 \mathrm{~s}$, and inside the fruits for $99 \pm 12 \mathrm{~s}$ (Figure 2).

Seeds collected from fruits that were open before the fires did not germinate in laboratory tests. For seeds collected from fruits that opened after the fire, the germinability was high for both plots: $79 \pm 12 \%$ and $69 \pm 14 \%$ for fruits in the plots burnt in June and August, respectively. Germination rate was not significantly different $(\mathrm{t}=1.725 ; \mathrm{p}>0.05)$ between plots. Seeds collected from closed fruits before the prescribed fires of June and August did not germinate.

Before the June fire, the median value of open fruits in the tagged individuals was zero. Two weeks after fire, the median value increased to $66.6 \%$ in the June plot (Figure 3 ) and no alteration was observed at this time in the percentage of open fruits in the August plot. The difference in percentage of open fruits between plots was significant $(\mathrm{p}<0.05)$ until two weeks after the prescribed fire of August. After the August fire, an increase in the percentage of open fruits was observed in this plot, as it 

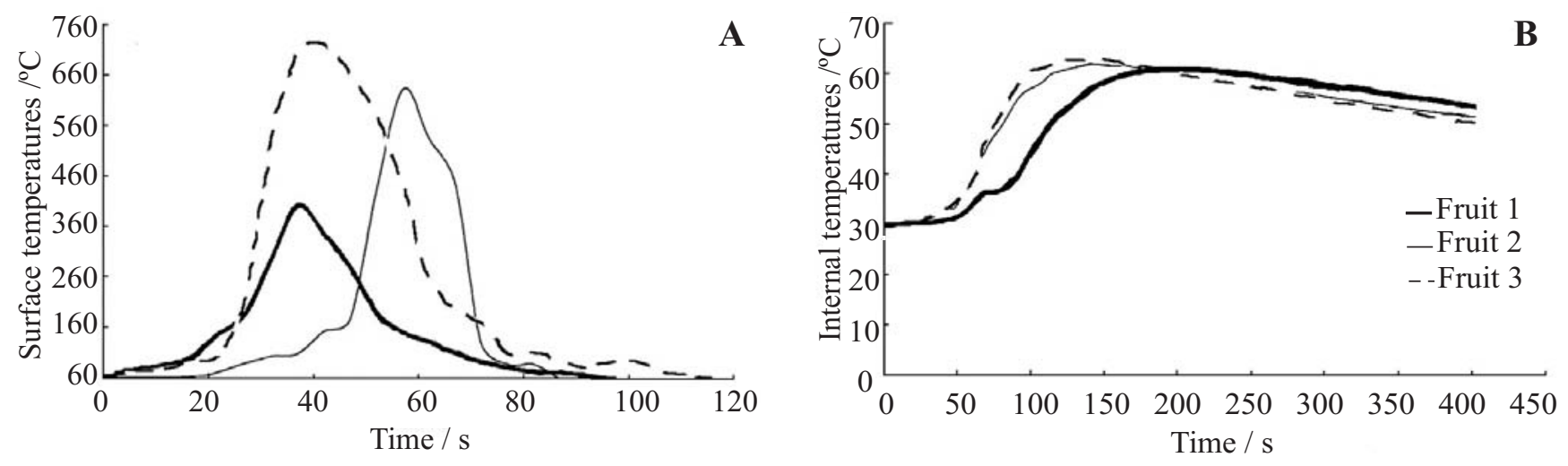

Figure 1. External (a) and internal (b) temperatures for three fruits of Kielmeyera coriacea during a prescribed fire in June of 2000 in a cerrado sensu stricto area at the Reserva Ecológica do IBGE, Brasília, Brazil.
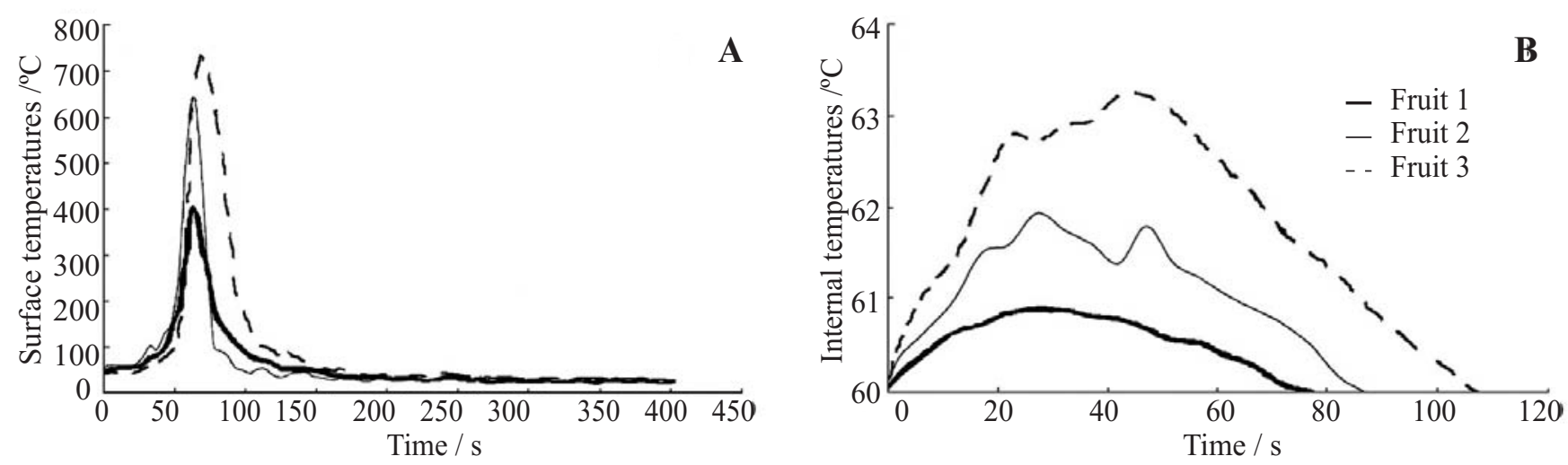

Figure 2. Duration of external (a) and internal (b) temperatures greater than $60^{\circ} \mathrm{C}$ for three fruits of Kielmeyera coriacea during a prescribed fire in June of 2000 in a cerrado sensu stricto area at the Reserva Ecológica do IBGE, Brasília, Brazil.
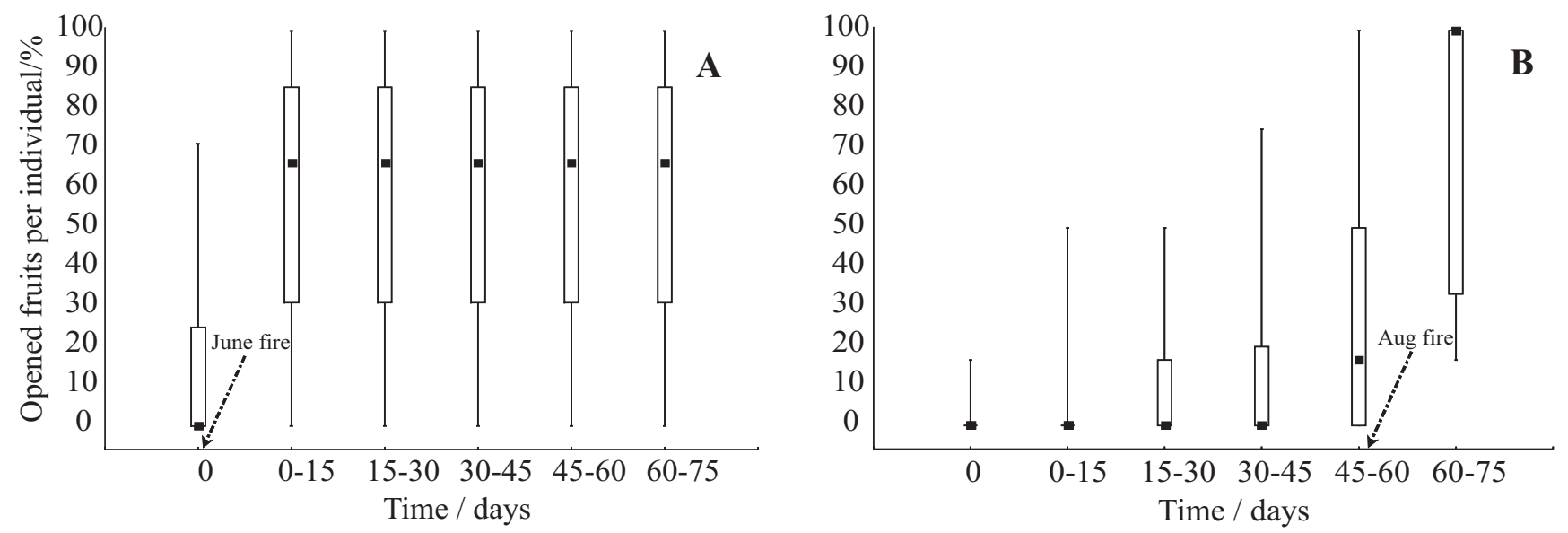

Figure 3. Median number of open fruits per individual of Kielmeyera coriacea in areas of cerrado sensu stricto (closed squares) submitted to prescribed biennial burnings at the beginning - June (a) and at middle - August (b) of dry season. Significant differences $(n=15 ; \mathrm{p}<0.05)$ in consecutive samples in each plot were observed only after the respective burning. Bars = inferior (25\%) and superior (75\%) quartiles; whiskers = maximum and minimum values. 
was observed after the prescribed fire of June. The percentage of fruits that did not open until the end of the subsequent rainy season was $41.2 \%$ and $34.4 \%$ in the plots burnt in June and August, respectively.

For closed fruits collected in the June plot, on the day of the fire, the relative water content (RWC) was $528.8 \pm$ $90.9 \%$, reducing to $422.0 \pm 72.5 \%$ two weeks later. Before the fire in the August plot RWC for the closed fruits was $403.3 \pm 25.0 \%$. In the laboratory, fruits opened when RWC reached $333.1 \pm 59.6 \%$. The differences between RWC of fruits collected before and 15 days after the June fire were significant $(\mathrm{t}=2.9026$; $\mathrm{p}<0.05$ ) but no difference was observed between fruits collected after the June fire and those collected before the August fire ( $t=0.7748$; $\mathrm{p}>0.05)$.

\section{DISCUSSION}

During the fire, surface temperatures as high as $734{ }^{\circ} \mathrm{C}$ were measured for fruits of Kielmeyera coriacea, with maximum internal temperatures of $63^{\circ} \mathrm{C}$. This value is lower than the lethal temperature of $70{ }^{\circ} \mathrm{C}$ reported by Mercer et al. (1994) for species with seeds without a hard coat such as $K$. coriacea. The high germination rate observed for the seeds collected in fruits that opened after the June and August fires is a measure of the efficiency of $K$. coriacea fruits in attenuating the high external temperatures. The role of fruit in protecting seeds during fires is emphasized by the absence of viable seeds among those collected from open fruits. Even for seeds with hard coats and dependent on fire to break dormancy, the direct exposure to high temperatures can be lethal to embryos (Hanley et al., 2001; Danthu et al., 2003).

The residence time for internal fruit temperatures greater than $60^{\circ} \mathrm{C}$ was not long enough to cause damage to the seeds. Internal temperatures may be related to the short residence time of high external fruit temperature during fires, fruit characteristics and moisture content (Judd and Ashton, 1991; Judd, 1993, 1994; Mercer et al., 1994). Bradstock et al. (1994) report that Hakea dactiloydes seeds may be able to withstand exposures of up to $300 \mathrm{~s}$ at $60^{\circ} \mathrm{C}$. Although the insulating capacity of fruits may be associated mainly to the fruit wall thickness (Judd, 1994), the high water content associated with the large size of $K$. coriacea fruits may also explain the values of internal fruit temperatures given that the evaporation of moisture prevents internal temperature from rising above $100^{\circ} \mathrm{C}$ until the fruit tissue has dried (Judd, 1993, 1994; Mercer et al., 1994).

More than $70 \%$ of the seeds from fruits that opened after the fires in the June and August plots germinated, but none from the closed fruits that were collected just before the fires, suggesting that the early dry season fire coincided with seed maturation (Figure 3). Fruit opening after the burnings may be a consequence of the death of branches caused by cambium temperatures greater than $70^{\circ} \mathrm{C}$ (Cirne, 2002). This will interrupt sap flow to the fruits, which may be the signal that initiates the final phase of seed development (pre-abscission), when they lose water and dry maturation occurs (Hay and Probert, 1995; Baskin and Baskin, 2001). Despite the effects of high temperatures, high rates of germination can also be achieved by inactivation of inhibitors of germination and/or by the release of chemical compounds necessary for this process (Bell and Williams, 1998; Whelan and Brown, 1998). However, for K. coriacea fire does not represent an essential factor for seed germination. The germination rates of $K$. coriacea seeds from fruits that were not exposed to fire reported by Oliveira and Silva (1993) were similar to those observed in the present study.

In the Cerrado, fruit opening and seed release of $K$. coriacea occur throughout the dry season, with a peak at the end of the season (Ribeiro et al., 1985, Oliveira and Silva, 1993), when wind conditions and the low relative humidity favor wind dispersal (Gottsberger and Silberbauer-Gottsberger, 1983). There is a synchronic release of seeds near the beginning of the rainy season, when the chances of germination are higher (Oliveira and Silva, 1993). In the present study, fruit opening occurred earlier after the June fire, with most of the fruits opening in the first two weeks after the fire. In the August plot, which represented a control treatment (without fire) for the June fire, most of the fruits remained closed during the same period (Figure 3). After the August fire, an intense peak of fruit opening also occurred in the two weeks following the fire, similarly to the pattern observed after the June fire. In both plots, seed release was anticipated by the fire independently of the timing of burning. Nevertheless, for the August plot, the lack of an unburned control prevented any clear distinction of the effects of fire from the phenological patterns of $K$. coriacea in fruit opening. 
Fruit opening after fire may occur as a function of exposure to the high temperatures that kill living tissues resulting in desiccation and subsequent rending of the fruit structure (Gill, 1976; Bradstock and Myerscough, 1981; Richardson et al., 1987; Lamont, 1991; Judd, 1994). A reduction in the relative water content (RWC) of closed fruits of $K$. coriacea was observed when comparing the values obtained before the June fire and those measured 15 days after the fire. The reduction in RWC of closed fruits collected before the fires in the June and August plots represent the natural pattern during the dry season, following the reduction of the air relative humidity. Although RWC of closed fruits measured after the fires is greater than the relative water content measured for fruit opening, the differences between pre and post fire RWC of fruits collected in the June plot, and the similarity between the RWC of fruits collected 15 days after the June fire and those collected before the August fire may indicate that the fire is accelerating fruit drying and anticipating the release of the seeds.

The adaptive significance of synchronic seed release after fire, as observed in the June and August plots, can be explained by the exploitation of favorable conditions for germination and establishment frequently occurring after fires (Coutinho, 1980; Whelan, 1985; Lamont et al., 1991; Bradstock et al., 1994). Also, wind dispersed seeds, such as in $K$. coriacea, can spread over greater distances as a consequence of the removal of the plant cover by fire, as observed by Coutinho (1977) for other woody species of the Cerrado.

Although fire may stimulate the release of seeds, it can also result in the mortality of a large proportion of seeds if the phenological patterns of the species results in seed release prior to late dry season fire. For $K$. coriacea, the opening of fruits before the fire $(13.2 \%$ of total in the June and $22.4 \%$ in the August plots - Figure 3) will result in death of seeds in the open fruits. Also, $41.2 \%$ of the fruits in the June plot and $34.4 \%$ in the August plot did not open after the fires, which represents an additional loss of seeds. A large proportion of fruits of $K$. coriacea failing to open after a fire was also observed by Landim and Hay (1996). Considering fruits that were open before the fires and the ones that did not open afterwards, the estimated loss of seeds was $54.2 \%$ in the June plot and $56.8 \%$ in the August plot. Also, the success of seed germination is frequently maximized if it occurs quickly after seed release (Bond, 1984; Cowling and Lamont, 1987; Whelan and Tait, 1995). Thus, the synchronic fruit opening at the beginning or the middle of the dry season represents further risks of seed death by increasing exposure time of the seed at the soil surface, since the rainy season is expected to start approximately four months after the June fire.

\section{CONCLUSIONS}

The questions addressed in this work were positively answered: K. coriacea fruits offer good thermal insulation for seeds during Cerrado fires; the duration of internal fruit temperatures above $60^{\circ} \mathrm{C}$ is not long enough to damage the seeds inside closed fruits exposed to the flames or to the hot air flow during fires; seeds from fruits that open after exposure to fire showed high germination rates, and seed release is anticipated independently of time of burning. However, the damage of viable seeds in fruits that are already open before the fires and the large number of fruits that do not open after the fires represent a considerable loss of the year's seed production.

Acknowledgements: This study was financed by funds from USDA/FS and CAPES. We thank the staff of the Reserva Ecológica do IBGE and the Thermobiology Laboratory of the University of Brasília for providing laboratory facilities, and Dr. F. R. Scarano, Dr. H. L. T. Zaluar, Dr. F. Borghetti and Dr. M. Haridasan for their useful comments on the manuscript.

\section{REFERENCES}

Almeida PD, Proença CEB, Sano SM, Ribeiro JF (1998) Cerrado: espécies vegetais úteis. EMBRAPA-CPAC, Planaltina.

Aoki H, Santos IR (1982) Características dos estratos arbustivos e arbóreos do Distrito Federal. Silvicultura em São Paulo 16:626-639.

Auld TD, O‘Connell MA (1991) Predicting patterns of post-fire germination in 35 eastern Australian Fabaceae. Aust. J. Ecol. 16:53-70.

Baskin CC, Baskin JM (2001) Seeds. Ecology, biogeography, and evolution of dormancy and germination. Academic Press, San Diego, CA, US.

Bell DT, Williams DS (1998) Tolerance of thermal shock in 
seeds. Aust. J. Bot. 46:221-223.

Bond WJ (1984) Fire survival on Cape Proteaceae influence of fire season and seed predators. Vegetatio 56:65-74.

Bradstock RA, Myerscough PJ (1981) Fire effects on seed release and the emergence and establishment of seedlings in Banksia ericifolia L.f. Aust. J. Bot. 29:521-531.

Bradstock RA, Gill AM, Hastings SM, Moore PHR (1994) Survival of serotinous seedbnks during bushfires: comparative studies of Hakea species from southeastern Australia. Aust. J. Ecol. 19:276-282.

Cardoso JM, Bates JM (2002) Biogeographic patterns and conservation in the South American Cerrado: a tropical savanna hotspot. Bioscience 52:225-233.

Cirne P (2002) Efeitos do fogo na regeneração de Kielmeyera coriacea (Spr.) Mart. (Guttiferae) em áreas de cerrado sensu stricto: mecanismos de sobrevivência e época de queima. Universidade de Brasília, Brasília, Brasil. PhD Thesis.

Cirne P, Scarano FR (2001) Resprouting and growth dynamics after fire of the clonal shrub Andira legalis (Leguminosae) in a sandy coastal plain in southeastern Brazil. J. Ecol. 89:351-357.

Cirne P, Zaluar HLT, Scarano FR (2003) Plant diversity, interspecific associations, and postfire resprouting on a sandy spit in a Brazilian coastal plain. Ecotropica 9:33-38.

Coutinho LM (1977) Aspectos ecológicos do fogo no cerrado. II - As queimadas e a dispersão de sementes de algumas espécies anemocóricas do estrato herbáceo subarbustivo. Bol. Botânica Univ. S. Paulo 5:57-64.

Coutinho LM (1980) As queimadas e seu papel ecológico. Brasil Florestal 44:7-20.

Coutinho LM (1982) Ecological effects of fire in Brazilian Cerrado. In: Huntley BJ, Walker B (eds.), Ecology of Tropical Savannas, pp.273-291. Springer Verlag, Berlin.

Cowling RM, Lamont BB (1987) Post-fire recruitment of four co-occurring Banksia species. J. Appl. Ecol. 24:645-648.

Danthu P, Ndongo M, Diaou M, Thiam O, Sarr A, Dedhiou B, Vall AOM (2003) Impact of bushfire on germination of some West African Acacias. For. Ecol. Manage. 173:1-10.

Eiten G (1972) The Cerrado vegetation of Brazil. Bot. Rev. 38:201-341.
Eriksson I, Teketay D, Granström A (2003) Response of plant communities to fire in an Acacia woodland and a dry Afromontane forest, southern Ethiopia. For Ecol. Manage. 177:39-50.

Gill AM (1976) Fire and the opening of Banksia ornata F. Muell. follicles. Aust. J. Bot. 24:329-337.

Gottsberger G, Silberbauer-Gottsberger I (1983) Dispersal and distribution in the cerrado vegetation of Brazil. Sonderband des Naturwissenschaftlichen Vereins in Hamburg 7:315-352.

Hanley ME, Fenner M (1997) Seedling growth of four firefollowing Mediterranean plant species deprived of single mineral nutrients. Funct. Ecol. 11:398-345.

Hanley ME, Fenner M, Ne’eman G (2001) Pregermination heat shock and seedling growth of fire-following Fabaceae from four Mediterranean-climate regions. Acta Oecol. 22:315-320.

Hay FR, Probert RJ (1995) Seed maturity and the effects of different drying conditions on desiccation tolerance and seed longevity in foxglove (Digitalis purpurea L.). Ann. Bot. 76:639-647.

Judd TS (1993) Seed survival in small myrtaceous capsules subjected to experimental heating. Oecologia 93:576-581.

Judd TS (1994) Do small Myrtaceous seed-capsules display specialized insulating characteristics which protect seed during fire? Ann. Bot. 73:33-38.

Judd TS, Ashton DH (1991) Fruit clustering in the Myrtaceae: seed survival in capsules subjected to experimental heating. Aust. J. Bot. 39:241-245.

Lamont BB (1991) Canopy seed storage and release: what's in a name? Oikos 60:266-268.

Lamont BB, Baker MJ (1988) Seed bank dynamics of a serotinous, fire-sensitive Banksia species. Aust. J. Bot. 36:193-203.

Lamont BB, Le Maitre DC, Cowling RM, Enright NJ (1991) Canopy seed storage in woody plants. Bot. Rev. 57:277-317.

Landim MF, Hay JD (1996) Impacto do fogo sobre alguns aspectos da biologia reprodutiva de Kielmeyera coriacea Mart. Rev. bras. Biol. 56:127-134.

Mercer GN, Gill AM, Weber RO (1994) A time-dependent model of fire impact on seed survival in woody fruits. Aust. J. Bot. 42:71-81.

Medeiros MB, Miranda HS (2005) Mortalidade pós-fogo em espécies lenhosas de campo sujo submetido a três quei- 
madas prescritas anuais. Acta bot. bras. 19:493-500.

Medeiros MB, Miranda HS (2008) Post-fire resprouting and mortality in Cerrado woody plant specie. Edinburgh J. Bot. 65:1-16.

Myers N, Mittermeier RA, Mittermeier CG, da Fonseca GAB, Kent J (2000) Biodiversity hotspots for conservation priorities. Nature 24:853-858.

Oliveira EP, Silva JCS (1993) Reproductive biology of two species of Kielmeyera (Guttiferae) in the cerrados of Central Brazil. J. Trop. Ecol. 1:67-79.

Ribeiro JF, Silva JC, Batmanian GJ (1985) Fitosociologia de tipos fisionômicos do Cerrado em Planaltina-DF. Rev. Bras. Bot. 8:131-142.

Richardson DM, van Wilgen BW, Mitchell DT (1987) Aspects of the reproductive ecology of four Australian Hakea species (Proteaceae) in South Africa. Oecologia 71:345-354.

Salgado-Laboriau ML, Ferraz-Vicentini KR (1994) Fire in cerrado 32,000 years ago. Curr. Res. Pleist.11:85-87.

Tyler CM (1995) Factors contributiing to postfire seedling establishment in chaparral: direct and indirect effects of fire. J. Ecol. 83:1009-1020.

Whelan RJ (1985) Patterns of recruitment to plant populations after fire in Western Australia and Florida. Proc. Ecol. Soc. Aust. 14:169-178.

Whelan RJ (1995) The Ecology of Fire. Cambridge University Press, Cambridge.

Whelan RJ, Brown CL (1998) The role of Callistemon fruits and infrutescences in protecting seeds from heat in fires. Aust. J. Bot. 46:235-239.

Whelan RJ, Tait I (1995) Responses of plant populations to fire: fire season as an understudied element of fire regime. CALMScience Supplement 4:147-150.

Williams P, Congdon RA, Grice AC, Clarke PJ (2004) Soil temperature and depth of legume germination during early and late dry season fires in a tropical eucalypt savanna of north-eastern Australia. Austral Ecol. 29:258-263.

Wright SJ, Bailey AW (1982) Fire Ecology. John Wiley and Sons, New York.

Zar JH (1996) Biostatistical Analysis. Prentice Hall, New Jersey. 